PRODUCTION

ENGINEERING ARCHIVES
2016, Vol. 12, No. 3, pp 38-41

ISSN 2353-5156 (print version)

ISSN 2353-7779 (online version)

Article history: Received:15.09.2016

Accepted: 24.09.2016

Online: 30.09 .2016

Available online on: http://www.qpij.pl

Exist since $4^{\text {th }}$ quarter 2013

\title{
Analysis of causes and effects errors in calculation of rolling slewing bearings capacity
}

\author{
Marek Krynke $^{1}$, Krzysztof Mielczarek ${ }^{2}$ \\ ${ }^{1,2}$ Institute of Production Engineering, Faculty of Management, Czestochowa University of Technology, Armii Krajowej 19B, \\ 42-201 Czestochowa, Poland, e-mail: krynke@zim.pcz.pl ${ }^{1}$, mielczarek@zim.pcz.pl ${ }^{2}$
}

\begin{abstract}
In the paper the basic design features and essential assumption of calculation models as well as the factors influencing quality improvement and improvement of calculation process of bearing capacity of rolling slewing bearings are discussed. The aim of conducted research is the identification and elimination of sources of errors in determining the characteristics of slewing bearing capacity. The result of the research aims atdeterminingthe risk of making mistakes and specifying tips for designers of slewing bearings. It is shown that there is a necessity fora numerical method to be applied and that real conditions of bearing work must necessarily be taken into account e.g. carrying structure deformations as the first ones.
\end{abstract}

Key words - FMEA method,slewing bearing, carrying capacity, quality

\section{Introduction}

Human desire to receive the best product has led to emergence of tools and methods of quality management that needs to monitor and act to strive for perfection of a product. The concept of quality is not limited to a product or service, it is a broader concept and can be applied everywhere (ULEWICZ R. 2013).

Alongsidewith the development of quality management, emerged many methods which have an impact on quality while sing data collected with the help of quality tools. Methods of quality management are more oriented on the analysis of collected data, however,tools have a more basic character and serve the collection of data concerning a given product. Animportant thing is the ability to see information contained in the methods and use of it to improve other processes or products (Ulewicz R., JeloneK D., MAZUR M. 2016).

The article presents the factors that aim to improve the quality and process of slewing bearing load capacity calculation. The objective of conducted research is identification and elimination of sources of errors in determining characteristics of slewing bearing capacity. The result of the research is determination of risks of making mistakes and providing advice for designers of slewing bearings. 


\section{Factors influencing the capacity and durability of the slewing bearings}

Slewing bearing is a subgroup of rolling element bearing commonly used in large industrial machineries such as turntable, steel mill cranes, offshore cranes, rotatable trolley, excavators, stackers, swing shovels, and ladle cars. A slewing bearing is basically a bearing with a gear wheel integrated in the inner or outer ring, which is subjected to a complex set of heavy loads. They typically support high axial $Q$, high tilting moment $M$ and high radial load $H$ (Fig. 1).

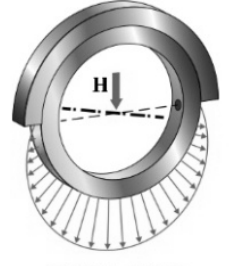

RADIAL LOAD

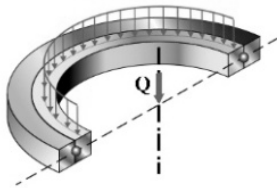

AXIAL LOAD

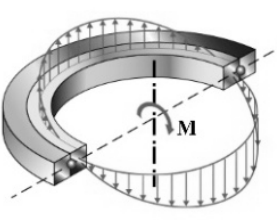

MOMENT LOAD
Fig. 1. Load distributions in a slewing bearing.

Source: http://www.silverthin.com/.

Slewing bearings are often critical production part. An unplanned downtime when a bearing breaks down can be very expensive due to the loss of production. Moreover, as replacement of large slewing bearing can take several months to arrive due to long manufacturing and delivery time; plants often carry spare bearing to guard against these unforeseen circumstances adding an extra cost. In order to prevent unplanned downtime, a condition monitoring and prognosis method is needed (KRYNKE M. 2015, ŚPIEWAK S. 2016).

There are many different types of slewing bearings depending on the number of rows and in the type of rolling elements. Thus, there are bearings with one, two and three rows, and the rolling elements can be balls or cylindrical rollers (SMOLNICKI T. 2013).

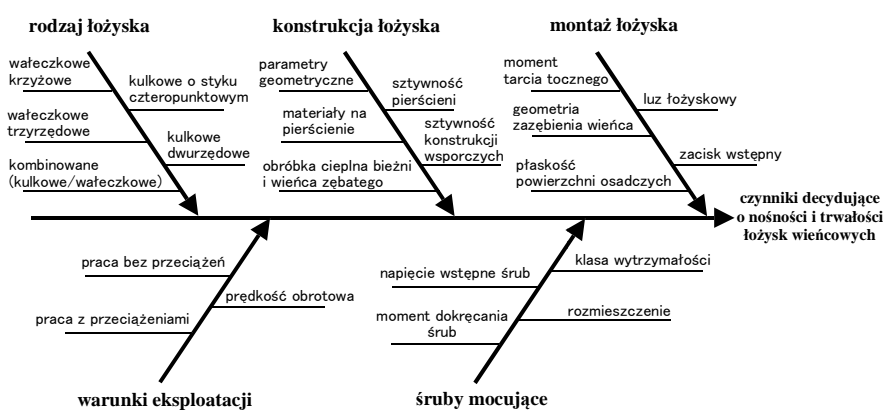

Fig. 2. Factors influencing the capacity and durability of the slewing bearings.
Slewing bearings designed and manufactured for a specific application requiring knowledge of the design of the device on which the bearing will work, the approximate dimensions of the bearings, the diameters of the bearing rings mounting screws locations, as well as all the types and magnitude of loads that are transmitted through the bearing (Fig. 2).

\section{Calculation of slewing bearings carrying capacity}

The load capacity of slewing bearings is determined by different calculation methods. Simple model calculations allow to determine the characteristics of the bearing under the condition of a number of simplifications. The consequence of the applied simplifications is an inaccurate assessment of actual bearing capacity (KANIA L. KRYNKE M. 2013). Load capacity of slewing bearing is dependent on a number of factors, such as (KRYNKE M., BORKOWSKI S. 2014):

- the flexibility of the bearing rings,

- the flexibility of fastening bolts on the bearing rings in the structure of the working machines,

- the sizes of the contact areas of rolling elements with raceways,

- nominal angle of action of the forces transmitted through the rolling elements, and its change under load bearings,

- the coefficient of adhesion of beads to the raceways,

- fill factor parts rolling around the circumference of the raceways of the bearing,

- clearance of the bearing,

- the flexibility of the supporting structures.

Static load rating of slewing bearings presented in graphs, called characteristics. Generally it is the curve described by the function $M(Q, H)$, where $M$ denotes the maximum value of the tilting moment, $Q$, the maximum axial force, and $H$ is the radial component of the load (Fig. 3). Component $H$ is often accepted as a constant value, which is determined by the functions $M(Q)$.

Source: own study 


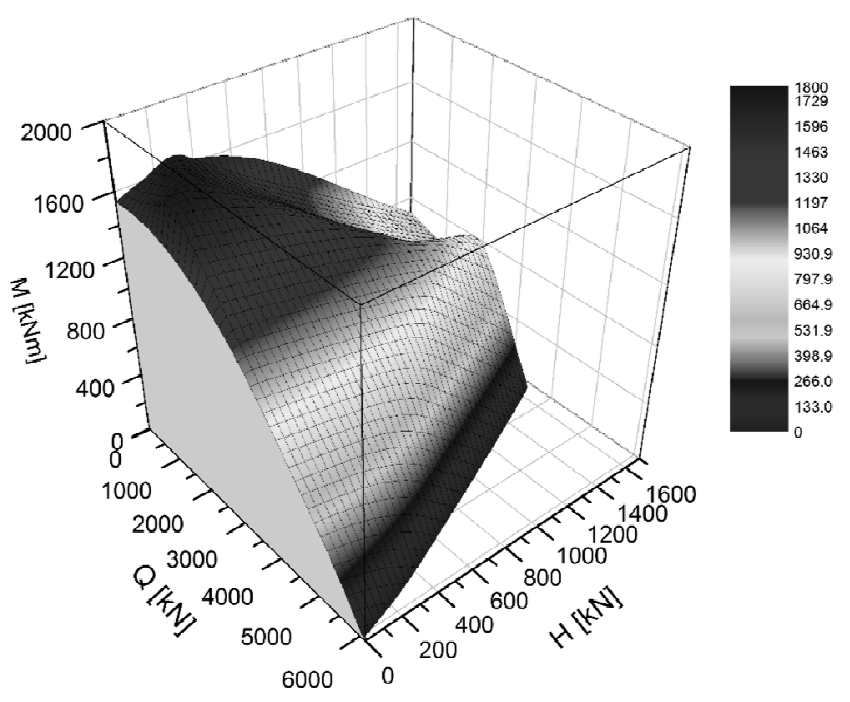

Fig. 3. 3D graph the static load of slewing bearing $M=f(Q, H)$.

Source: own study.

\section{Quantitative assessment of the causes of errors in determining the bearing capacity}

To determine the risk associated with the determination of the bearing capacity of rolling bearings, which are as a result of the simplifications adopted in models of computation, the FMEA method was used. This method analyzes the causes and consequences of errors. The purpose of this analysis-search for possible causes and effects of errors in the design stage and eliminate them before it becomes a finished product. It has also wide application at the stage of operation where there are already failures caused by errors in the implementation of products, that is, in the production process. This method is mainly used in project and research activities and production (JAGUSIAK-KOCIK M. KNOP K. 2016).

In studies the risk was determined by identifying the criteria for selection of coefficients, i.e.: $\mathrm{R}-$ the risk of error, $\mathrm{Z}$ - the error value and $\mathrm{W}-$ the difficulty of accounting errors in the calculations. A number of priority risk was defined by using dependencies:

$$
\mathrm{RPN}=\mathrm{R} \times \mathrm{Z} \times \mathrm{W}
$$

In the FMEA analysis, it is assumed that the causes of the error estimation of the bearing capacity, where the number of priority $1<\mathrm{RPN}<100$, does not require the introduction of protection measures. But if the priority number $\mathrm{RPN} \geq 100$, you should take precautions for reasons arising out of errors in determining the bearing capacity. Tab. 1 shows the individual factors and risks that are there, if not their relative in the calculations of the bearing capacity of rolling slewing bearings.

The greatest risks related to incorrect evaluation of the slewing bearing capacity include ignoring susceptibility of bearing supporting structures for machine and bearing clearance.

Table 1. Analysis of the causes and consequences of errors in the calculation of the bearing capacity of the slewing bearings.

\begin{tabular}{|c|c|c|c|c|c|c|c|c|}
\hline \multirow{2}{*}{ Potential error } & \multirow{2}{*}{$\begin{array}{l}\text { The effects of er- } \\
\text { rors }\end{array}$} & \multirow{2}{*}{$\begin{array}{l}\text { The cause } \\
\text { of the error }\end{array}$} & \multirow{2}{*}{$\begin{array}{l}\text { Tools/ } \\
\text { research } \\
\text { methods }\end{array}$} & \multicolumn{4}{|c|}{$\begin{array}{l}\text { The current } \\
\text { state }\end{array}$} & \multirow{2}{*}{ Recommended action } \\
\hline & & & & $\mathrm{R}$ & $\mathrm{Z}$ & $\mathrm{W}$ & $\frac{Z}{\alpha}$ & \\
\hline $\begin{array}{l}\text { Ignoring the flexi- } \\
\text { bility of bearing } \\
\text { rings }\end{array}$ & $\begin{array}{l}\text { Revaluation static } \\
\text { load capacity }\end{array}$ & $\begin{array}{l}\text { The assumptions } \\
\text { made in the model } \\
\text { computing }\end{array}$ & $\begin{array}{l}\text { Classical compu- } \\
\text { tation models } \\
\text { bearings }\end{array}$ & 5 & 4 & 7 & 140 & $\begin{array}{l}\text { Construction of numerical } \\
\text { models using FEM }\end{array}$ \\
\hline $\begin{array}{l}\text { Ignoring the bolts } \\
\text { of the bearing ring }\end{array}$ & $\begin{array}{l}\text { Revaluation static } \\
\text { load capacity }\end{array}$ & $\begin{array}{l}\text { Simplification of the } \\
\text { model computing } \\
\text { with respect mount- } \\
\text { ing bolts }\end{array}$ & $\begin{array}{l}\text { Classical compu- } \\
\text { tation models of } \\
\text { bearings, without } \\
\text { the possibility of } \\
\text { input of the bolts }\end{array}$ & 6 & 3 & 6 & 108 & $\begin{array}{l}\text { In numerical calculations } \\
\text { the finite element method } \\
\text { to model the bolts with } \\
\text { beam elements with pre- } \\
\text { tension }\end{array}$ \\
\hline $\begin{array}{l}\text { Ignoring changes } \\
\text { in the nominal } \\
\text { contact angle of } \\
\text { balls }\end{array}$ & $\begin{array}{l}\text { The risk of damag- } \\
\text { ing the edges of the } \\
\text { raceway bearing, } \\
\text { the underestimation } \\
\text { of the static load ca- } \\
\text { pacity }\end{array}$ & $\begin{array}{l}\text { Calculations of ball } \\
\text { bearings on models of } \\
\text { computation relating } \\
\text { to roller bearings, in } \\
\text { which there is the } \\
\text { change of angle of } \\
\text { contact }\end{array}$ & $\begin{array}{l}\text { Classical and } \\
\text { numerical model } \\
\text { for the calcula- } \\
\text { tion of bearings }\end{array}$ & 7 & 4 & 6 & 168 & $\begin{array}{l}\text { In computational models, } \\
\text { the balls should be replaced } \\
\text { element special which } \\
\text { allows, in particular, in } \\
\text { accordance with the change } \\
\text { in the angle of operation of } \\
\text { the parts of rolling due to }\end{array}$ \\
\hline
\end{tabular}




\begin{tabular}{|c|c|c|c|c|c|c|c|c|}
\hline & & & & & & & & portable loads \\
\hline $\begin{array}{l}\text { Ignoring the bear- } \\
\text { ing clearance }\end{array}$ & $\begin{array}{l}\text { Revaluation static } \\
\text { load capacity, } \\
\text { Incorrect meshing } \\
\text { geometry of gear } \\
\text { ring and pinion }\end{array}$ & $\begin{array}{l}\text { Simplification of } \\
\text { computational mod- } \\
\text { els without the possi- } \\
\text { bility of introducing } \\
\text { bearing clearance }\end{array}$ & $\begin{array}{l}\text { Calculation of re- } \\
\text { placement chara- } \\
\text { cteristics of the } \\
\text { rolling elements }\end{array}$ & 7 & 5 & 3 & 105 & $\begin{array}{l}\text { Clearance introduced into } \\
\text { the computational model by } \\
\text { moving the replacement } \\
\text { material characteristic for } \\
\text { rolling elements }\end{array}$ \\
\hline $\begin{array}{l}\text { Ignoring the initial } \\
\text { clamp }\end{array}$ & $\begin{array}{l}\text { The underesti- } \\
\text { mation of the mo- } \\
\text { ment of rolling fric- } \\
\text { tion during rotation } \\
\text { of the bearing }\end{array}$ & $\begin{array}{l}\text { Simplification of } \\
\text { computational mod- } \\
\text { els without the possi- } \\
\text { bility of introducing } \\
\text { preliminary clamp }\end{array}$ & $\begin{array}{l}\text { Calculation of re- } \\
\text { placement chara- } \\
\text { cteristics of the } \\
\text { rolling elements }\end{array}$ & 8 & 2 & 3 & 48 & $\begin{array}{l}\text { preliminary clamp through } \\
\text { the substitution bias cha- } \\
\text { racteristics of the materials } \\
\text { for parts of rolling }\end{array}$ \\
\hline $\begin{array}{l}\text { Ignoring the flex- } \\
\text { ibility of systems } \\
\text { of reference and of } \\
\text { bearing used for } \\
\text { machine }\end{array}$ & $\begin{array}{l}\text { Revaluation static } \\
\text { load capacity }\end{array}$ & $\begin{array}{l}\text { Lack of knowledge of } \\
\text { the geometry of sup- } \\
\text { porting structures at } \\
\text { the stage of cal- } \\
\text { culation of the bear- } \\
\text { ing capacity }\end{array}$ & $\begin{array}{l}\text { Classical compu- } \\
\text { tation models } \\
\text { bearings }\end{array}$ & 9 & 6 & 9 & 486 & $\begin{array}{l}\text { It is necessary to know the } \\
\text { structure of bearing instal- } \\
\text { lation and execute a compu- } \\
\text { tational model taking into } \\
\text { account the entire structure } \\
\text { of the machine relative to } \\
\text { the site of rotation }\end{array}$ \\
\hline $\begin{array}{l}\text { Ignoring the de- } \\
\text { viation from flat- } \\
\text { ness of the surface } \\
\text { retaining }\end{array}$ & $\begin{array}{l}\text { Revaluation static } \\
\text { load capacity }\end{array}$ & $\begin{array}{l}\text { The assumptions of } \\
\text { the model calculation }\end{array}$ & $\begin{array}{l}\text { Classical compu- } \\
\text { tation models } \\
\text { bearings }\end{array}$ & 6 & 4 & 7 & 168 & $\begin{array}{l}\text { The deviation from flatness } \\
\text { must be considered in the } \\
\text { geometry of the model cal- } \\
\text { culation, concerning the } \\
\text { seats of the bearing }\end{array}$ \\
\hline
\end{tabular}

Source: own study.

\section{Summary}

The study analyzes the methods quality of calculating the slewing bearing static load capacity. In relation to the classical methods used currently are considered the main factors that formed the basis of a simplification of the classical methods of calculating the bearing capacity, namely:

- the flexibility of the bearing rings,

- the flexibility of the bolts securing the ring to the structures it is installed,

- deformation and change of contact geometry in the contact zone of rolling elements contact with the raceways of the bearing,

- flexibility and deformation of the supporting structure of the working machine caused by the load.

In the light of the obtained results, when determining the bearing capacity of slewing bearings, located on load-bearing structures, do not have a corresponding stiffness, it is necessary to consider that flexibility is not only rings, bearings and bolts, as well as exposure to the entire load-bearing system of the working machine.

\section{Literature}

1. UlewiCZ R. Ocena efektywności funkcjonowania Systemu Zapewnienia Jakości. Production Engineering Archives. Vol. 1(1) pp. 35-38, 2013.

2. KANIA L. KRYNKE M. Computation of the general carrying capacity of slewing bearings. Engineering Computations, vol. 30, no 7. pp. 1011-1028, 2013.

3. KRYNKE M., BORKOWSKI S. Wpływ postaci konstrukcyjnej podzespołu wsporczego na dystrybucję obciążeń $\mathrm{w}$ łożysku wieńcowym. Przegląd Mechaniczny. No 7-8. pp. 23-29, 2014.

4. UleWiCZ R., JELONEK D., MAZUR M. Implementation of logic flow in planning and production control. Management and production engineering review. Vol. 7, issue 1, pp. 89-94, 2016.

5. JAGUSIAK-KOCIK M. KNOP K. Wykorzystanie wybranych narzędzi zarządzania jakością i metody FMEA w przedsiębiorstwie produkującym konstrukcje spawane dla maszyn.Techniczne aspekty inżynierii produkcji. Oficyna Wydawnicza SMJiP. s. 61-72, 2016.

6. ŚPIEWAK S. Methodology for calculating the complete static carrying capacity of twin slewing bearing. Mechanism and Machine Theory. Vol. 101, pp 181-194, 2016.

7. SMOLNICKI T. Wielkogabarytowe toczne węzły obrotowe. Zagadnienia globalne i lokalne. Oficyna wydawnicza Politechniki Wrocławskiej, Wrocław, 2013.

8. KRYNKE M. The dynamic state monitoring of bearings system. Production Engineering Archives. Vol. 6 (1). pp. 35-38, 2015. 